\title{
A CRITICAL STOCK TAKE OF MALAWI'S 19 MAY 2009 ELECTIONS \\ Processes, Outcomes and Challenges
}

\section{Blessings Chinsinga}

Dr Blessings Chinsinga teaches in the Department of Political and Administration Studies of Chancellor College, University of Malawi e-mail: kchinsinga@yahoo.co.uk

\begin{abstract}
This article reviews critically Malawi's fourth consecutive general elections since the country's momentous return to multiparty democracy in May 1994. The results of the May 2009 elections marked a complete departure from the familiar patterns of voting along tribal, ethnic or regional lines. The main argument of this article is that the historical uniqueness of the 2009 elections has failed to act as a catalyst for the fundamental and sustainable democratic transformation that was widely prophesied by observers and commentators in the immediate aftermath of the polls. This illustrates, inter alia, that Malawi is still a defective democracy, whose politics are neither democratic nor undemocratic. The major lesson is that democracy cannot flourish if a society does not have any consciousness of its own contradictions and does not set out social practices to provide rules for society to manage its interests and objectives with equity, justice and fairness.
\end{abstract}

\section{INTRODUCTION}

On 19 May 2009 Malawi held its fourth consecutive general elections in the 15 years since the historic transition to democracy. The Democratic Progressive Party (DPP) and its presidential candidate won the elections with potentially epoch making landslide victories both at parliamentary and at presidential levels. Of the 192 seats contested in the parliamentary elections, the DPP won 113 compared to 27 seats for the Malawi Congress Party (MCP) and 17 for the United Democratic Front (UDF). The rest of the seats went to independent candidates, who won 32, and to three smaller political parties, the Alliance for Democracy (AFORD), the Malawi People's Party (MPP) and the Malawi Forum for Unity and Development (Mafunde), each of which won a single seat. President Bingu wa Mutharika was 
re-elected with twice as many votes (2946103) as those polled by his closest rival, John Tembo, of the surprising MCP/UDF electoral alliance.

This article undertakes a critical appraisal of Malawi's fourth consecutive general elections, paying particular attention to the pre-election political context and electoral preparations, election day and the election results and their implications, as well as to a series of post-election developments, especially in terms of the way they dovetail with the prospects for fundamental and sustainable democratic transformation.

The outcome of the election heightened expectations of a new beginning in the country's quest for such a democratic transformation because they defied the regional, ethnic and tribal patterns that had seemed so intractable in the previous three elections. As early as 1995 Malawi's elections were stereotyped as merely regional or ethnic censuses (Kaspin 1995; Chinsinga 2009). The fact that the DPP's victory de-regionalised and de-ethnicised the country's configuration and alignment of political forces and interests was therefore widely regarded as a potential catalyst for turning the corner in the country's quest for fundamental and sustainable democratic transformation.

This review of the 2009 elections is inspired by an institutional approach to understanding democratic transition and transformation, which is mainly concerned with making sense of how institutions, understood as the rules of the game, emerge, function and change in the establishment of a viable democratic dispensation (Olsen 2008).

The main argument of this article is that while the outcome of the elections was historic in signalling a complete departure from the familiar patterns of voting along regional faultlines it has not really lived up to the immediate post-election euphoria as heralding a new phase in the form and substance of democratic politics in the country. This illustrates, inter alia, that the country is still very much a defective democracy. The major characteristic of defective democracies is that they have difficulty in establishing constitutional guarantees and the rule of law and in institutionalising free and fair elections (Merkel \& Croissant 2004).

The rest of the paper is organised as follows: the next section delineates briefly the institutional perspective for understanding the processes of democratisation, the third section sets the context for understanding the dynamics of the political milieu in May 2009 as well as the preparations for the poll. The fourth section, drawing mainly on the reports of various observer missions both local and international, examines the outcome of the elections, including how the polling day passed off. The fifth section addresses the significance of the poll in relation to its historic outcome and the subsequent implications for the country's quest and prospects for sustainable democratic transformation. The sixth and final section offers some concluding remarks. 


\section{DEMOCRATISATION FROM AN INSTITUTIONAL PERSPECTIVE}

As the rules of the game, institutions give order to social relations, reduce flexibility and variability of behaviour and restrict the possibilities of a one-sided pursuit of self-interest (March \& Olsen 2006). Consequently, democratisation is seen as a process of establishing democratic institutions and making them work. This is considered to be a defining prerequisite because 'institutions are markers of a polity's character, history, vision and identity' (Olsen 2008, p 10). Democratising countries are thus expected not only to establish a range of democratic institutions such as free and fair elections, an elected parliament, a free press, an independent judiciary and a vibrant civil society but also to allow these institutions to function efficiently and effectively.

This is quite fundamental to successful democratic transformation as it prevents regimes in transition either degenerating into defective democracies or breaking down altogether. Defective democracies are stuck in transitional mode while being regarded by many elites and the population as adequate solutions to acute problems experienced during previous authoritarian regimes. The total breakdown of the democratisation process is inevitable, since the process of establishing institutions of any kind is not a politically neutral process. Processes of institutional formation, maintenance and change are inherently subjects of contestation because ultimate outcomes distribute advantage and disadvantage to different groups and interests in different and often new ways (Leftwich \& Hogg 2007). Potential winners tend to favour change, while potential losers are inclined to defend the status quo.

The key assumption is that institutions in emerging democracies will improve with the passage of time (Rakner \& Svasand 2005) because voters, candidates and administrators will have progressively gained experience of the demands, values, ideals and practices of a democratic political dispensation. In other words, the political culture of emerging democracies is expected to adapt to the intrinsic demands of a democratic political dispensation. However, most countries are struggling to get to a stage where democracy is the only game in town because of the preponderance of informal over formal institutions (Cammack, Mutebi, Kanyongolo \& O'Neil 2007; Chinsinga 2008a). This is attributable to the enormous weaknesses in the implementation of the norms and rules of governance and of the guarantees of human and civil rights, the authority of which depends on overall institutional quality and society's general respect for these institutional arrangements.

Thus, the success or failure of electoral processes can be understood using this perspective, with election management bodies assuming centre stage since they are entrusted with the responsibility presiding over the electoral rules for 
the game. In the election literature the major assumption is that the quality of election management will improve over time through a process of institutional learning (Rakner \& Svasand 2005). This is the case because electoral processes are repeated by the same set of actors over time, the processes are evaluated, and corrective measures are put in place in subsequent elections. By this logic, the elections of 19 May 2009, as the fourth consecutive general elections, should surely have been a better managed.

\section{THE PRE-ELECTION CONTEXT}

\section{The political context}

The electoral dynamics of the May 2009 elections were, to a very great extent, shaped by the enduring legacy of the previous elections, in 2004. The single most important legacy of the run-up to the May 2004 elections was the failure of former President Muluzi of the UDF to extend his term of office beyond the maximum two five-year consecutive terms allowable by the Republican Constitution (Dulani 2005; Murithi 2007).

For the UDF it was imperative to extend Muluzi's term of office to ensure continuity in his ambitious development agenda (Daily Times 27 August 2001). Any change of leadership at this juncture, it was argued, would interrupt the agenda, which could only be seen through to its logical conclusion if his tenure could be extended for at least another five-year term. If President Muluzi were to pave the way for new leadership from within the UDF it would be like starting again from a blank slate on the development front (Chinsinga 2003; Lwanda 2005). Thus, for the ardent supporters of this view, it did not matter whether Muluzi was succeeded by a fellow UDF politician since they felt that his potential successors would not match his leadership stature (The Nation 1 August 2001, 18 September 2001). All potential successors to President Muluzi, both within and outside the UDF, were branded 'maize husks', madeya in the vernacular.

It is against this backdrop that the UDF government orchestrated the tabling of the Open Terms Bill in Parliament on 4 July 2002 by an Alliance for Democracy legislator. Specifically targeting s 83(3) of the Constitution, the rationale of the Open Terms Bill was that the provisions of section 83 (3) are considered to infringe upon people's power to elect into office of president the person of their choice and renew his mandate for as many times as they may wish him or her to serve them'. ${ }^{1}$ The Bill failed to secure the requisite two-thirds majority and

1 For details of the Bill see The Malawi Government Gazette Supplement Containing Private Members Bills, 24 May 2002. 
thus was not passed. This did not, however, mark the end of President Muluzi's aspiration to prolong his tenure. Instead of further pursuing an Open Terms Bill the strategy shifted to the proposal of a constitutional amendment that would extend the tenure of the president from two to three five-year terms. This proposal, popularly referred to as the Third Term Bill, was, however, never formally tabled in Parliament because of fierce opposition from both within and outside the UDF. Civil society and faith based organisations rallied against it under the auspices of the Forum for the Defense of the Constitution (FDC) (The Nation 19 October 2002, 24 October 2002).

Muluzi's determination to push for the extension of his term of office led to the resignation of several senior UDF officials with leadership aspirations. Among many others these included former vice-state-president Justin Malewezi, former UDF vice-president Aleke Banda, Brown Mpinganjira, Harry Thompson, and Gresham Naura (The Nation 8 October 2002). The spate of resignations was triggered mainly because of Muluzi's use of s 65 of the Constitution, which regulates floor crossing in Parliament, facilitating the amendment of s 65 to extend floor crossing outside Parliament as a strategy to deal with dissent against the proposal (Dulani \& Van Donge 2005). S 65 was amended to reflect the fact that legislators may lose their seats if they associate with organisations whose objectives are political in nature.

These developments eventually propelled the rise to political prominence of Bingu wa Mutharika, who, until then, was relatively unknown. He had gone into politics after his forced retirement as secretary general of the Common Market for Eastern and Southern Africa (COMESA) in the late 1990s and stood as a presidential candidate in the June 1999 elections on the ticket of the United Party (UP), which he had founded. The UP failed to win a seat and Mutharika had quite a dismal showing, winning less than 0.5 per cent of the total national vote. He dissolved his party in 2001 and joined the UDF-led government, initially as deputy governor of the Reserve Bank, and became Minister of Economic Planning and Development before finally being anointed as a surprise successor to Muluzi, leading the UDF presidential ticket in partnership with Cassim Chilumpha, an ardent critic of Muluzi's bid for an extension of his tenure.

Muluzi presented the choice of Mutharika as a unanimous decision of the UDF's National Executive Committee (NEC), a claim that was widely disputed by the majority of the senior NEC members. For this reason the choice of Mutharika, considered by many not only as a UDF outsider but also as a political lightweight, was characterised as a strategic ploy by Muluzi to retain influence over the dayto-day running of government affairs (Dulani 2005; Murithi 2007).

This view was somewhat underscored by the subsequent amendment of the UDF constitution to replace the position of party president with that of national 
party chairman, to which Muluzi was elected in clearly stage managed elections. Mutharika's entire presidential campaign was conducted by Muluzi, punctuated with brief occasions on which Mutharika was merely asked to greet people and quickly outline his vision for the country (Lwanda 2005; Chinsinga 2009). It was therefore widely expected that Mutharika would be Muluzi's obedient successor and Muluzi would continue to pull the strings from his position as the ruling party's chairman.

This was not to be. Barely eight months after the 2004 elections Muluzi and Mutharika fell out dramatically over a destructive power struggle between Mutharika as head of government and Muluzi as head of the UDF. While Muluzi wanted to dictate the shape and form of government affairs, as widely expected, Mutharika was determined to create an independent base of political power and legitimacy, especially since he had not been the architect of his own political campaign and had won the presidency with the slimmest of margins.

Mutharika's determination to extricate himself from Muluzi's omnipresent political shadow was apparent in his inauguration speech, in which he called for a new beginning, underpinned by inclusive governance, genuine commitment to poverty reduction by reorienting the people's mindsets and attitudes, and a total crackdown on corruption by implementing a zero tolerance anti-corruption strategy (Lwanda 2005; Phiri 2008). The persistent political tensions created by Mutharika's desire to create his own political base and Muluzi's desire to pull strings from behind the scenes eventually culminated in Mutharika breaking away from the UDF to form his own party, the Democratic Progressive Party (DPP) in February 2005. This led to an unprecedented development. The DPP became the governing party and the UDF went into opposition (Lwanda 2005; Chinsinga 2006). The Muluzi-Mutharika political fallout demonstrated that a subdued cat can become a tiger when it assumes a throne.

The dispute plunged the country into a state of tension which left it teetering on the brink of political paralysis until the eve of the 2009 elections. The repercussions manifested mainly in acrimonious engagement between the government and the opposition, driven, to a great extent, by the imperatives of neopatrimonialism. Taking advantage of the strength of combined numbers the opposition was determined to wrest power from the minority government, which had only six legitimate MPs elected in by-elections in December 2005, while the government was determined to stay in power at all costs. This resulted, inter alia, in the excessive judicialisation and informalisation of politics, as each party was determined to achieve its goals. Both the government and the opposition made use of formal and informal means to advance their own selfish motives (Cammack, Mutebi, Knyongolo \& O’Neil 2007; Chinsinga 2008a).

The protracted antagonism between the government and the opposition not 
only created a tense political atmosphere it also greatly battered and exacerbated the institutional fragility of the foundations of Malawi's democracy. Parliament was particularly affected because of massive defections of parliamentarians from the UDF to the DPP. Instead of functioning as a platform for national dialogue, debate and compromise, the august house degenerated into a political battleground characterised by endless battles waged, among other ways, through s 65, threats of impeachment of the president and deliberately orchestrated rejection of presidential nominees to key public offices.

Of all these battles, the one relating to s 65 assumed centre stage (The Nation 9 April 2009). The main challenge was that Mutharika's DPP, as a new party at the helm of government, did not have legislators of its own apart from the six who were elected on its ticket in the December 2005 by-elections. The majority of the legislators, estimated at more than 70, who either publicly or tacitly aligned with the DPP-led government belonged to the opposition political parties, mainly the UDF and the MCP. Therefore, working as a block and taking advantage of their combined strength in Parliament the goal of the opposition was to petition the Speaker to invoke s 65 against those legislators deemed to have crossed the floor to the DPP. In doing so the opposition block principally used the budget as a bargaining chip (The Nation 17 April 2008a, b, 22 June 2008, 30 June 2008).

For three consecutive fiscal years the budget was delayed for about three months as the opposition was determined to force the Speaker to invoke s 65 . While the Supreme Court of Appeal had upheld the constitutional validity of s 65 following a presidential referral, as provided for in the Constitution, the government side managed to create roadblocks that made it extremely difficult for the speaker to invoke it against opposition legislators deemed to have crossed the floor to the DPP (The Nation 24 April 2008). In the referral, the president argued that 'section 65 dealing with the issue of crossing the floor should be deemed not to be compatible with or contradictory to section 32 of the [constitution] and should be deleted from the constitution' (The Nation 26 March 2006).

Mutharika and his DPP-led government survived by means of a series of constitutional and governance transgressions as well as a groundswell of public sympathy. The populace tolerated some blatant constitutional and governance infractions on the part of Mutharika and his administration because it was widely acknowledged that they were operating in a very hostile environment (Chinsinga 2008a; Chilenga 2008). The widespread public sympathy was buoyed by the impressive achievements in areas of economic management, food security and infrastructure development, particularly the road network. These developments eventually forced the opposition to turn to the 2009 elections as a last ditch attempt to eject Mutharika from the helm of government.

Muluzi, who was particularly bitter about Mutharika's betrayal, took it upon 
himself to lead the political battle against him in his capacity as self-proclaimed master political strategist. He therefore offered himself as the UDF's presidential candidate, arguing that he was best suited to dislodge Mutharika from power since he had put him there in the first place (The Daily Times 24 January 2009, 6 January 2010). The battle lines were thus drawn for what promised to be hugely competitive elections. Muluzi desired a comeback primarily to get rid of Mutharika; the MCP's John Tembo was desperate to seize power as he strongly believed that the previous elections had been stolen from him and Mutharika was determined to stay on for a full second term, buoyed by the success of his administration in engineering unprecedented economic recovery, ensuring food security and an impressive track record in infrastructural development, particularly roads (Chinsinga 2008a).

\section{Preparations}

The verdict on the preparations for the elections is inconclusive. While the Electoral Commission (EC) displayed the authority and flexibility to address a range of challenges the 2009 elections were characterised by the same weaknesses that had affected previous elections. These include a delayed response to the electoral calendar, leading to a failure to re-demarcate constituency boundaries; a poor and delayed registration exercise, leading to an inadequate voters' roll, with many names missing; excessive incumbency advantages; and a delay in the vote count (Rakner 2009; Chinsinga 2009). The situation might, perhaps, have been different, since the electoral preparations were, to a very great extent, shaped by the political context preceding the polls.

\section{The political context and electoral preparations}

Two main issues are significant to an understanding of the way the EC handled the preparations for the polls. These were excessive delays in the constitution of the EC itself and the protracted controversy surrounding the candidature of former president Muluzi (CPSP 2009).

The delays in the constitution of the EC inevitably had a serious domino effect on the electoral calendar. The commission was only constituted towards the end of 2008 after a protracted legal battle between the government and the opposition over the legality of the procedure used by the president to identify EC commissioners. The EC had to be reconstituted because, by the end of 2007, it could not take any binding decisions since the contracts of five of its eight commissioners had expired (The Daily Times 19 December 2007). When the president finally appointed the commissioners the opposition objected to their appropriateness and fought over it all the way to the Supreme Court of Appeal 
(The Nation 18 January 2008). However, the opposition withdrew the case before the Supreme Court of Appeal could make a determination on the matter.

The opposition's argument was that the president had transgressed the law that requires him to appoint EC commissioners in consultation with leaders of those parties represented in Parliament, and that he had not ensured that parties were represented on the EC in proportion to their parliamentary strength (The Nation 16 January 2008). The opposition further argued that the commissioners who had been appointed could not guarantee a level playing field for the election because they were well known as sympathisers of the DPP (Chinsinga 2008b).

The battle over the appointment procedures was principally a strategic attempt by each side to contest the elections in circumstances that would guarantee it a favourable outcome. If the commissioners were to have been appointed according to the established practice the DPP would have been underrepresented since it was a minority party in Parliament and the EC would have been dominated by UDF and MCP representatives. The EC is thus quite a pivotal institution in the battle to gain control of the state through elections.

Muluzi's candidature presented a considerable challenge to the EC in its preparations for the polls. The UDF had endorsed him as its candidate in April 2008, but according to s 83(3) of the Constitution he was ineligible because he had already served the maximum of two consecutive five-year terms as president of the country. However, his supporters, inspired by the word 'consecutive' in the section, believed Muluzi was eligible because he had taken a five-year break from the presidency.

The EC was hesitant to make a determination on the matter, fearing that, given the perceived popularity of Muluzi, if they did so it would plunge the country into violence. The commission only ruled on 21 March 2009 that in terms of s 83(3) Muluzi was ineligible to stand (Kanyongolo 2009; Rakner 2009). The decision was a blow to the UDF. It was too late to identify an alternative presidential candidate since it was felt that only Muluzi had the pedigree to take on Mutharika successfully. The UDF referred the EC's decision to the Constitutional Court, which, on 16 May, a mere three days before the elections, upheld the EC's ruling. This left the UDF without a presidential candidate, forcing the party to strike a last minute electoral alliance with the $\mathrm{MCP}$, as both were desperate to eject Mutharika from the helm of government (see EU 2009; EISA 2009; COG 2009; The Nation 26 April 2009).

\section{Constituency demarcation}

The constituency demarcation exercise did not take place, as required by law, in the lead up to the 19 May elections. According to s 76(2a) of the Constitution 
the EC is required to review existing constituency boundaries at intervals of not more than five years and alter them in accordance with principles laid down in the Constitution. Because of the delay in constituting the EC the commission failed to carry out the exercise. However, the official justification for violating this constitutional requirement was that it would only make sense to review the boundaries of the existing constituencies after the results of the 2008 population and housing census had been officially released (EC 2009).

The previous constituency demarcation exercise had been carried out in 1998, thus both the 2004 and the 2009 elections were held on the basis of the 193 constituencies delimitated then. The exercise was widely criticised as being driven by selfish and partisan interests rather than the principles laid down in the Constitution, which lays down that the constituency demarcation exercise should be based on population density, ease of communication, geographical features, and existing administrative areas.

Informal processes linked to traditional leaders' authority, MPs' self interest, and regional concerns, coupled with financial constraints, reportedly undermined the EC's capacity to re-demarcate constituencies on the basis of these principles. The failure to do so was not only a gross constitutional violation but also, in a way, undermined the credibility and integrity of the election since 'discrepancies noted more than 10 years ago continue, and had probably increased with the new age groups reaching voting age' (Rakner 2009, p 12).

\section{Voter registration}

A new voters' roll had to be created because the one used in May 2004 was inadequate. The voter registration exercise was initially scheduled to run from 2 August to 28 November 2008 but was extended to the end of December 2008. The exercise was marred by serious logistical challenges. There were only about 870 field data capture equipment packs to cover about 3900 voter registration centres and the unexpected breakdown of many of them in the field made the registration exercise even more problematic, leading to the extension of the registration period with substantial financial and time costs (Coker, De Brito, Chinsinga \& Banda 2009).

The voter registration exercise was negatively affected by time constraints. A much needed second inspection of the voters' roll was not carried out despite the discovery of serious errors when it was first inspected, between 30 March and 3 April. By 11 May a corrective audit of the roll had only been carried out in 3611 of 3897 registration centres, which made it impossible to carry out a second inspection without having to change the election date, which would have required parliamentary approval (Rakner 2009; EISA 2009). 
The audit was hindered by poor archiving and retrieval of materials from the voter registration exercise and it is estimated that only 42 per cent of registrations were checked. This forced the EC to implement emergency measures on election day in response to numerous inaccuracies and omissions detected during the verification period. The measures included having at each polling station an additional list of voters according to the numeric voter registration code, and allowing voters with a valid voter ID to vote, even if they could not be found on either the official alphabetical or the additional numerical roll.

\section{Civic and voter education}

The EC is mandated by the Presidential and Parliamentary Elections Act (PPEA) to coordinate civic and voter education, working in partnership with political parties and civil society organisations (CSOs). The major challenge in the 2009 elections was that the programmes were not rolled out in time. Seventy CSOs were accredited to provide voter and civic education and each was allocated several constituencies in which to focus their activities, to ensure the whole country would be covered (MESN 2009; see also The Daily Times 25 June 2009). However, of the 70 accredited CSOs only 35 were funded from the UNDP basket fund to conduct voter and civic education and even that funding came rather too late to have the desired strategic impact. Civic and voter education activities were adversely affected by several other factors - they were rolled out long after the voter registration exercise had already started; there was little attempt to ascertain the appeal and impact of many of the messages; as a result of logistical challenges to the distribution of materials from the EC's headquarters most CSOs did not stick to messages that were approved by the EC. In addition, because the CSOs had too little time in which to cover all aspects of civic and voter education, voters were overloaded with information (Coker, De Brito, Chinsinga \& Banda).

There was debate about whether the higher voter turnout, estimated to be 78 per cent, was due to the success of the education campaign. The popular view is that this is unlikely since the campaign was, by all accounts, a failure. The alternative view is that the higher turnout was mainly due to the fact that Malawians were bored with the political stalemate between the government and the opposition, epitomised by the s 65 standoff, and with Muluzi's wish to stand for a third term. The opposition thus made itself popular over unpopular issues.

\section{Media and the abuse of public resources}

There is a host of legislation regulating media coverage and the abuse of public resources for the purposes of advancing political goals. For instance, s 63 of the 
PPEA states explicitly that every political party is entitled to have the substance of its campaign reported on the public broadcasters and s 194(4) of the Constitution prohibits the use of state resources for campaigning for a particular political party. In partnership with the Malawi Communications Regulatory Authority (MACRA) the EC is expected to enforce this legislation to ensure a level playing field in the electoral processes (Chiyamwaka 2009).

While the legislative framework relating to communications is generally restrictive, to allow for fully vibrant media to flourish, the EC, in partnership with the Media Council of Malawi (MCM), developed a code of ethics as a selfregulatory mechanism for journalists and media houses reporting on the 2009 elections. The conclusion was that coverage of the elections, particularly by the public broadcasters, was unbalanced in favour of the DPP, as the governing party (EC 2009). Of the private media houses only Joy radio station rivalled the public broadcasters, devoting 84.4 per cent of its coverage to the UDF (Coker, De Brito, Chinsinga \& Banda 2009).

The EC's Media Monitoring Unit indicated that the Malawi Broadcasting Corporation (MBC) dedicated 97.6 per cent of all electoral coverage from 17 January to 24 April 2009 to the DPP and, in the same period, Television Malawi (TVM) gave it 94.4 per cent of its coverage. Apart from Joy, the private media had offered fairly balanced coverage. These findings were mirrored by MACRA's own Media Monitoring Unit, covering a different, but overlapping period. According to MACRA, in the period between 1 March and 17 May the DPP received 86 per cent of the positive coverage from the MBC and 97 per cent from the TVM. In the same period Joy radio gave slightly more than 50 per cent of its positive coverage to the UDF, the decline influenced, to a large extent, by the last minute electoral alliance between the UDF and the MCP.

The president and his DPP benefited massively from public resources in promoting their political causes. The president took advantage of incumbency to abuse public resources under the guise of performing ostensibly government functions when these were clearly campaign events. He also used state resources, particularly vehicles and security services, to facilitate his campaign activities (EISA 2009; EU 2009). The vehicles used for campaign purposes were taken mainly from parastatal bodies such as the Electricity Supply Commission of Malawi (ESCOM), the Agricultural Development and Marketing Corporation (ADMARC) and Malawi Telcoms Limited (MTL).

The paradox was that MACRA, which is supposed to regulate the process, was implicated in the DPP's abuse of public resources. MACRA reportedly funded the production of DPP posters and T-shirts, justifying its action as a contribution to the civic and voter education campaign.

While the EC boldly condemned the ruling party's abuse of state resources 
and the blatant bias of the public broadcasters, it was unable to take any decisive action. The legislative framework in terms of what it can do beyond admonishing such practices is rather ambiguous. Even MACRA's powers are constrained by a weak legislative framework which governing parties have, since the transition to democracy in May 1994, been reluctant to reform for purely selfish political reasons (Coker, De Brito, Chinsinga \& Banda 2009; Chiyamwaka 2009).

\section{The EC's questionable decisions}

Notwithstanding the fact that the EC presided over the 19 May 2009 elections in an extremely difficult political context it made two decisions that attracted scathing criticism and substantially undermined its credibility as an independent arbiter of the electoral process.

The EC unilaterally hiked the nomination fees for both presidential and parliamentary candidates. The fee for parliamentary candidates was raised from MK5000 to MK100 000, while that for presidential candidates was increased from MK50 000 to MK500 000, refundable only to the successful candidates (The Daily Times 4 December 2008).

Despite the fact that the EC, as a means of ensuring consensus, constitutes a committee of those political parties who are contesting an election to deliberate on decisions affecting key aspects of the election, it increased the nomination fees without discussing the proposals with this committee.

The commission also yielded to the demand of the DPP's presidential candidate to change his name on the ballot paper (using his first name instead of his surname) long after the nomination period had closed, contravening the law stipulating that the name on the ballot should be the one used at the time of nomination. The change meant that his name appeared first on the ballot paper, giving him a huge advantage (Rakner 2009; Chiyamwaka 2009). Several studies of elections show that the position of candidates on the ballot paper has considerable influence on the results (Rakner 2009).

The net effect of these decisions was to undermine the integrity of the EC as an impartial referee over the electoral process since the decisions were widely seen, especially among opposition parties, to have been influenced by the governing party to undercut the competitive edge of the opposition. It was extremely difficult for many parties to raise MK100 000 for their candidates to stand in all 193 constituencies. The DPP paid the nomination fees for all its parliamentary candidates, while candidates of other political parties struggled to raise the fees on their own.

The suspicion that the EC's decision was influenced by the governing party was heightened by the way the finances of James Nyondo, an independent 
presidential candidate, came under state scrutiny. Nyondo had offered to pay nomination fees for independent MPs across the country in return for their support. Malawi's anti-money-laundering legislation was invoked and Nyondo was charged and his accounts frozen almost for the duration of the nomination process. As part of his bail conditions he had to report to the police at regular intervals during a crucial phase of the electoral campaign, yet the case was not pursued after the election. By the time he was charged, though, he had paid nomination fees for about 120 independent candidates.

\section{Parallel vote tally centre}

Civil society's proposal to establish a parallel vote tally centre (PVT), a proposal strongly backed by donors, was one of the contentious issues in the run-up to the polls. The PVT was justified as a means of enhancing the credibility and integrity of the outcome of the election. As a mechanism for determining through a reasonable sample whether the official count reflected the actual vote, the PVT would have provided an independent audit mechanism for assessing the credibility and authenticity of the results and detecting whether they had been manipulated.

For civil society and donors the PVT would have allayed fears of election results being rigged by the EC working in collaboration with the governing party; a widespread perception in the 1999 and 2004 polls (Patel 2010). However, the proposal was fiercely resisted by both the EC and the DPP. They argued that the establishment of a PVT would undermine the constitutional integrity of the EC as the sole body charged with the responsibility for conducting elections in the country.

\section{THE RESULTS}

Sixteen parties contested the 2009 elections. However, only six fielded presidential candidates. The seventh candidate was the independent, James Nyondo. A record 1184 candidates contested the 193 parliamentary seats. The DPP fielded 193 candidates, the UDF 171, the MCP 134, the People's Progressive Movement (PPM) 50, the New Rainbow Coalition (NARC) 33, the Alliance for Democracy (AFORD) 29, the Republican Party (RP) 24 and the People's Transformation Party (PETRA) 16. The remaining parties fielded a limited number of candidates, with a good number only managing one, the party president. There were 480 independent candidates.

The increase in the number of independent candidates is attributed to increasingly undemocratic candidate selection exercises, especially in the major political parties. The choice of most candidates does not reflect the will of the 
electorate as much as it does that of the political party machines (Patel \& Mpesi 2009; Magolowondo \& Svasand 2009).

Election day passed off quite peacefully despite fears that the majority of the voters might be disenfranchised because of the enormous number of errors in the voters' register. As pointed out above, however, the problem was averted by the use of a numeric register to help identify voters by their voter identification numbers. In addition, voters who did not appear on either register but whose ID number fell within the polling station range were allowed to vote. This worked out very well, to the extent that there were insignificant incidences of voters being turned away without voting (EISA 2009; EU 2009; COG 2009). The turnout was 78 per cent, a dramatic surge from the record low of 59 per cent in the 2004.

Although there were a few minor hiccups these did not have any significant impact on the overall integrity of the voting exercise. Polling staff as well as security officials conducted themselves professionally, although, in some cases, the roles of security personnel and party agents were unclear in relation to cases of assisted voting. Polling stations opened and closed as scheduled, although there were reports of some running short of materials (EISA 2009). All constituencies were involved except one in Blantyre, where the poll was postponed because of the death of one of the candidates just days before election day.

There were, however, some serious problems with the transmission of the election results from district headquarters to the National Tally Centre. There is consensus that the counting process at the polling centres was quite transparent and accountable. In some cases, however, counting was done in extremely difficult circumstances because of poor light. The EC made an effort to provide each polling centre with a generator to ensure adequate lighting, but the generators did not always function as expected.

Party representatives were present at the polling stations and had the right to a copy of the certified results. This allowed parties recourse to legal redress in the event of huge discrepancies in the tally of the final results (EISA 2009; COG 2009). The transmission of the results from the district headquarters to the National Tally Centre was problematic due to a combination of factors that led to a total breakdown of the fax transmission system. These factors included a lack of adequate training, the complete absence of systems of checks and balances and a lack of quality assurance guarantees (EISA 2009; EU 2009). The EC eventually resorted to using hard copies from the constituency returning officers, which expedited the process somewhat, but at the expense of security measures and auditing to identify and correct errors.

The EC announced the results of the elections on 22 May 2009, a substantial improvement on previous elections (Rakner 2009). The results of the presidential elections were announced after 93.2 per cent of the votes from 3634 of 3897 
polling stations had been counted. The EC argued that the 670090 votes from the remaining 19 constituencies would not alter the overall outcome. The conduct of the 19 May 2009 elections was, perhaps, aptly summed up by the Malawi Electoral Support Network (MESN), which observed in its final report that:

... overall, electoral officials properly reconciled ballots, leaving no room for speculations ... 90\% of all party agents got a copy of the polling station results form and $82 \%$ of all polling stations posted their results outside, minimal differences between total results as released by the EC and percentages calculated by MESN as indicated by the fact that MESN report puts runner up John Tembo at 30.3\% while the EC said he got $30.7 \%$.

Daily Times 29 June 2009

This enhanced the credibility of the EC, especially since one of the contentious issues in the run-up to the elections was the proposal that a PVT be established to guarantee the credibility of the final outcome.

The results of the elections are summed up in Tables 1 and 2.

Table 1

Malawi Presidential election results 2009

\begin{tabular}{|l|c|c|}
\hline \multicolumn{1}{|c|}{ Candidate } & Percentage of votes & Number of votes \\
\hline Bingu wa Mutharika (DPP) & 66.17 & 2963820 \\
\hline John Tembo (MCP) & 30.49 & 1365672 \\
\hline Kamuzu Chibambo (PETRA) & 0.79 & 35358 \\
\hline Stanly Masauli (RP) & 0.76 & 33982 \\
\hline Loveness Gondwe (NARC) & 0.72 & 32432 \\
\hline James Nyondo (Independent) & 0.61 & 27460 \\
\hline Dindi Nyasalu (AFORD) & 0.45 & 20150 \\
\hline Total & $\mathbf{1 0 0}$ & $\mathbf{4 4 7 8 8 7 4}$ \\
\hline
\end{tabular}

Source: Electoral Commission Presidential and Parliamentary Report 2009, p 2 
Table 2

Malawi parliamentary election results 2009

\begin{tabular}{|l|c|c|}
\hline \multicolumn{1}{|c|}{ Party } & Percentage of seats & Number of seats \\
\hline DPP & 58.9 & 113 \\
\hline Independents & 16.7 & 32 \\
\hline MCP & 14.1 & 27 \\
\hline UDF & 8.9 & 17 \\
\hline AFORD & 0.52 & 1 \\
\hline MAFUNDE & 0.52 & 1 \\
\hline MMP & 0.52 & $\mathbf{1 9 2}$ \\
\hline Total & $\mathbf{1 0 0}$ & \\
\hline
\end{tabular}

Source: Electoral Commission Presidential and Parliamentary Report 2009, p 3

The results of the elections were a surprise. Most observers had anticipated a close contest between the DPP and the opposition MCP / UDF's electoral alliance, led by the MCP's presidential candidate, John Tembo. The DPP not only secured an overwhelming share of the seats (113) its presidential candidate won twice as many votes as his closest rival. The MCP and the UDF were beaten to third and fourth places respectively by the independent block of MPs, which, with 32 seats, came a distant second to the DPP (Chinsinga 2009; Rakner 2009).

There was also an improvement in the representation of women in Parliament. In the May 2004 elections women constituted only 14 per cent of the 193 parliamentarians. The proportion jumped to 22 per cent in 2009, a significant improvement under the first-past-the-post system. The improvement is attributed to the $50 / 50$ campaign that was sponsored by a consortium of donors led by Norway in collaboration with the Ministry of Gender and Child Development as a strategy for increasing women's participation in politics. The campaign was motivated by the fact that women are grossly underrepresented in politics in particular and public life in general despite constituting about 52 per cent of the national population (Malumelo \& Njikho 2009).

While the rest of the presidential candidates, including former president Muluzi, graciously conceded defeat to Mutharika, the MCP's presidential candidate challenged the credibility of the results (Daily Times 28 May, 29 May, 29 June 2009). Several parliamentary candidates also protested against the results. Like Tembo they argued that the election was marred by excessive irregularities such as alleged tampering with the figures by presiding officers (Rakner 2009). 
Tembo's reaction triggered instant instability in his party, with some of its executives arguing that it was pointless to complain about the results because they simply reflected the will of the voters. They stressed that the most honourable thing for Tembo to do would be to resign to pave the way for new leaders who would revive the political fortunes of the MCP. These party executives, led by the late Ishmael Chafukira, constituted themselves into a taskforce for leadership change that has had a tremendous impact on opposition politics in the post-May 2009 era. The DDP worked with this MCP faction to devise a change in the standing orders governing the election of the leader of the opposition.

Even before the first Parliament was convened a substantial number of independent MPs began to align themselves with the DPP. They argued that they had been forced to stand as independents because they were frustrated by the way in which the primary elections to identify party candidates had been conducted. The exercise of choosing party candidates for general elections is becoming an increasingly important source of political patronage among influential senior party executives determined to push certain individuals as a means of rewarding them for their political loyalty (Patel \& Mpesi 2009).

The results of the May 2009 elections defied the regional, ethnic and tribal patterns of voting that had seemed so entrenched in the previous three elections (Chinsinga 2009). The outcome, therefore, challenged some beliefs in political circles about regional, ethnic and tribal voting patterns in the country. Zeleza (2009) characterised the results in polemical terms, arguing that they were a cautionary tale for those who tend to analyse African politics in oversimplified ethnic and cultural terms and underestimate the capacity of African voters to act in their best interests as rational political players.

The elections were far from an ethnic or regional stereotype but instead reflected the aspirations of the people of Malawi to an issue-based political order. The outcome was thus widely interpreted as a vote of no confidence by the populace in self-serving politicians who are obsessed with narrow interests instead of championing a bigger picture reflective of the country's national interest.

\section{SIGNIFICANCE OF THE ELECTIONS}

These elections were quite significant for two reasons. Firstly, they not only drew the curtain on the political careers of the nationalist generation of political leaders but they were also closely fought. Secondly, the outcome marked a complete departure from the familiar pattern of people voting along regional, tribal or ethnic lines.

All the first-generation politicians are past their prime. The 2009 elections, therefore, offered them a last realistic chance for active involvement in politics, 
which made the elections even much more competitive. Former president Muluzi desired a comeback primarily to get rid of Mutharika, who, as his handpicked successor had, he felt, betrayed him; Tembo, believing that the May 2004 elections had been stolen from him, was making a last ditch effort to make his way to the helm of government and Mutharika was determined to stay on for a full second term, banking on his impressive performance during his first term, notwithstanding that his government operated in a hostile environment (Chinsinga 2008b).

The elections led, for the first time since the transition to democracy in the mid-1990s, to the birth of a political party with a truly national appeal and outreach. This was a big shock to the MCP/UDF electoral alliance, which had banked on regional and ethnic cards to usher them into power. Consequently, these two parties, instead of articulating a credible alternative, were concerned with how they would share the anticipated spoils. The MCP/UDF electoral alliance's platform remained shrouded in secrecy apart from uninspiring public pronouncements of a commitment to eject Mutharika from the presidency at any cost. The MCP even forgot to include the fertiliser subsidy programme in its election manifesto despite the fact that it was a central plank in its platform and that the party had credited itself with being the brains behind the programme.

This clearly did not inspire hope in voters, engender confidence or foster optimism about a better future. On the contrary, the secrecy invoked fear, raised suspicion and triggered uncertainty. This was inevitable given the political track record of the two leaders at the helm of the MCP/UDF electoral alliance. The country's economy had almost collapsed, corruption became rampant, and development virtually stagnated on Muluzi's watch and there is a popular myth that John Tembo was the brains behind most of the atrocities committed during Kamuzu Banda's one-party dictatorship.

According to the Afrobarometer survey results the dismal performance of the opposition political parties could also be construed as a backlash against the s 65 standoff. Up to 76 per cent of the respondents believed Parliament should prioritise budget discussions over other constitutional matters, including s 65 (Tsoka \& Chinsinga, 2009). The DPP's success could be attributed to the government's solid track record in several sectors. The economy, which had been ailing under Muluzi, had been effectively revived; the road infrastructure had been improved and new roads built in areas where people had believed they would see no improvement in their lifetime without a substantial injection of donor funds; the spread of corruption had been somewhat contained; and, following the successful implementation of the subsidy programme that had been fiercely resisted by donors, the country had become a beacon of hope in the realm of food security after years of battling with chronic food insecurity. 
Given the historical nature of the results the 2009 elections were widely regarded as a potentially defining moment in the country's quest for sustainable democratic transformation. Among other things, the outcome presented a golden opportunity to fast track the country's democratic transformation by establishing an inclusive system of governance that would make every Malawian a part of the new beginning. In this regard, a major task would be to clear the excessive legislative backlog that made it difficult to implement some of the reforms that are fundamental to sustainable democratic transformation.

Most of the country's laws, enacted to regulate political, economic and social life in a hugely restrictive one-party authoritarian political dispensation, are archaic and inconsistent with the demands and ideals of democracy (Kanyongolo 2009; Chinsinga 2009).

However, several developments since the elections have effectively shattered the prospects for the accelerated and sustainable democratic transformation forecast by most observers and commentators in the immediate aftermath. In fact, most of the government's practices, policies and laws have threatened to undermine the democratic foundations of the country. They have, in fact, the potential to reverse, if not to undo entirely the democratic gains achieved thus far.

The government has declared that it will ban all CSOs that are critical of its performance, and criticising government has been declared unconstitutional (Weekend Nation 27 March 2010). The justification is that its overwhelming victory has given the government a mandate to do as it pleases. All parliamentary committees are chaired by DPP MPs, including those such as the Public Accounts Committee, the Public Appointment Committee and the Budget and Finance Committee, which play vital roles in promoting a robust system of checks and balances (The Nation 23 November 2009). The standing orders governing the election of the leader of the opposition were changed to involve the entire Parliament, in an attempt to target John Tembo, who, as leader of the secondlargest party, would automatically have become leader of the opposition (The Nation 18 November 2009; Daily Times 25 November 2009). The new procedures have, however, been quashed by the courts as being unconstitutional (Weekend Nation 8 May 2010; Malawi News 8-14 May 2010).

There have also been several legislative changes whose overall effects do not augur well for the quest for fundamental and sustainable democratic transformation. The Local Government Act (LGA) has been subjected to sweeping amendments which ultimately amount to the reversal of the democratic disposition of the country's local government system (The Nation 3 February 2010; Daily Times 10 February 2010).

In addition, the Electoral Law has been amended to empower the president 
to decide on the date of local government elections (LGEs) - formerly set in the Local Government Act (LGA). This is a cause of concern because LGEs have been postponed continuously since May 2005. The amendments to the LGA were justified on the basis of efficiency and effectiveness but clearly at the expense of the democratic robustness of the local government system as envisaged in the initial framing of the legislation.

The Police Act has been amended to empower the police to undertake searches without warrants as long as they have reasonable suspicion that a crime has been committed (Weekend Nation 21 November 2009; The Nation 10 February 2010). Taken together, these developments have created a generalised and undefined sense of anxiety in the country underpinned by the retreat of various segments of society from constructive public debate and critical engagement, both of which are vital for fundamental and sustainable democratic transformation.

\section{CONCLUDING REMARKS AND REFLECTIONS}

The elections of 19 May 2009 were generally a success despite the fact that the Electoral Commission prepared for them in extremely difficult circumstances. Both local and international observers judged the process to be free, although not necessarily fair. The playing ground for political parties was far from being level and the public broadcasters were heavily biased in favour of the governing party. This resulted in a media war between the public broadcasters and Joy radio station, which backed the UDF. This essentially reflected the failure of MACRA to exercise its powers in partnership with the EC to regulate the political playing field.

The governing DPP also had preferential access to public resources for campaigning purposes, contrary to s 194(3) of the Constitution. The MACRA was implicated in the DPP's scheme of abuse of public resources, which, by any account, was a serious indictment of its credibility as an impartial regulator of the electoral process. However, regardless of these challenges, the EC managed to pull off a relatively successful election. Election day passed off peacefully and with no reports of voters being disenfranchised, despite serious errors in the voters' register.

The results of the elections were historic, with the DPP registering landslide victories in both presidential and parliamentary elections, rupturing the established tradition of Malawians voting on regional or ethnic lines. This development inspired hope that the elections might mark a turning point in the country's quest for fundamental and sustainable democratic transformation. In some circles it was heralded as an opportunity to domesticate or create a Malawioriented brand of democracy. However, these hopes have been effectively dashed following a series of developments since the elections. The government's practices, 
policies and laws since May 2009 threaten to undermine the foundations of a robust democratic nation, if not reverse altogether the democratic gains thus far.

These developments demonstrate that Malawi is very much a defective democracy. They denote a regime in transformation that has not achieved consolidation as a liberal democracy but which, at the same time, can no longer be considered an autocratic regime since it has established an electoral regime that essentially functions along democratic lines (Merkel \& Croissant 2004). Defective democracies often emerge in the course of attempts to entrench or practice constitutional order, hence most defects can be traced to the weakness and non-implementation of the norms and rules of governance that are the main drivers of fundamental and sustainable democratic transformation.

The experience of 19 May 2009 and subsequent developments therefore demonstrate, inter alia, that it is not the mere practice of and adherence to textbook democracy that delivers equity, prosperity and justice but rather the determination of the country's leaders to invent developmental democracy and the new democratic paradigms needed to achieve progressive social change (Kasongo 2005; Chinsinga 2008). There can thus be no real democracy if a society is not conscious of its own contradictions, does not allow political debate, and does not outline the social practices necessary to provide rules for the society to manage its interests and objectives with equity, justice and fairness.

\section{REFERENCES}

\section{Publications}

Cammack, D, F Mutebi, F Kanyongolo \& T O'Neil. 2007. Neopatrimonial Politics, Decentralization and Local Government: Uganda and Malawi in 2006. Working Paper 2, Good Governance, Aid Modalities and Poverty Reduction. Advisory Board for Irish Aid.

Chilenga, M. 2008. Dikastrocracy: Is it Undermining Democracy in Malawi? Towards the Consolidation of Malawi's Democracy: Occasional Paper Series, East and Central Africa No 11. Malawi: Konrad-Adenauer-Stiftung.

Chinsinga, B. 2003. 'Lack of Alternative Leadership in Democratic Malawi: Some Reflections Ahead of the 2004 General Elections'. Journal of Nordic African Studies 12(1).

—. 2006. Voter Apathy in Malawi: A Critical Appraisal. Lilongwe: Centre for Multiparty Democracy.

—_. 2008a. 'Decentralization and Poverty Reduction in Malawi: A Critical Appraisal'. In C Gordon and H Thomas (eds). Decentralization, Poverty 
Reduction and Conflict Management in Africa. Amsterdam: University of Amsterdam Publishers.

- 2008b. Malawi's Democracy project at a Crossroads. Towards the Consolidation of Malawi's Democracy: Occasional Paper Series, East and Central Africa No 11. Malawi: Konrad-Adenauer-Stiftung.

- 2009. 'Malawi's Political Landscape between 2004 and 2009'. Paper presented at the May 192009 Malawi Post Election Conference organised by GTZ Forum for Dialogue and Peace, Crossroads Hotel, 23 to 26 June.

Chiyamwaka, B. 2009. 'The Role of the Media'. Paper presented at the May 192009

Malawi Post Election Conference organised by GTZ Forum for Dialogue and Peace, Crossroads Hotel, 23 to 26 June.

Civic and Political Space Platform (CPSP). The Status of Governance Report in Malawi 2009. Lilongwe: Civic and Political Space.

Coker, T, M de Brito, B Chinsinga \& J Banda. 2009. Outcome Evaluation of the Support to Electoral Reform and Elections in the Malawi Project and the 50/50 Programme. Lilongwe: UNDP.

Commonwealth Observer Group (COG). 2009. 2009 Malawi Elections Final Report. Available at: www.genderandtrade.org/documment/181889/34293/35144 /152078/211206/2009_Malawi_ele

Dulani, B. 2005. 'Consolidating Malawi's Democracy? An Analysis of the 2004 Malawi General Elections'. Africa Insight 36(1).

_ \& J van Donge. 2005. 'A Decade of Legislative-Executive Squabble in Malawi'. In M Salih (ed). African Parliaments: Between Governance and Government. Palgrave Macmillan.

EISA.2009. EISA Election Observer Mission Report: Malawi Presidential and Parliamentary Elections 19 May 2009. Johannesburg: EISA Election Observer Mission Report No 30 .

European Community (EC). 2009. Second Update on 2009 Parliamentary and Presidential

Elections. Available at: www.csr.org.mw/2009-elections / MECUpdate

European Union (EU). 2009. Malawi: Presidential and Parliamentary Elections May 2009. European Union Election Observation Mission.

Gloppen, S \& E Kanyongolo. 2006. The Judiciary’. In N Patel \& L Svasand (eds). Government and Politics in Malawi. Kachere Books 33. Balaka: Montfort Media.

Government of Malawi 2002. Malawi Government Gazette Supplement Containing Private Members' Bills.

Kanyongolo, E. 2009. 'The Role of the Judiciary in Elections in Malawi in 2009'. Paper presented at the May 192009 Malawi Post Election Conference organised by GTZ Forum for Dialogue and Peace, Crossroads Hotel, 23 to 26 June.

Kasongo, T. 2005. 'The Problematics of Liberal Democracy and Democratic Process: 
Lessons for Deconstructing and Building African Democracies'. In T Kasongo (ed). Liberal Democracy and its Critics in Africa. Dakar: CODESRIA.

Kaspin, D. 1995. 'The Politics of Ethnicity in Malawi's Democratic Transition'. Journal of Modern African Studies 33.

Leftwich, A\& H Hogg. 2007. 'The Case for Leadership and the Primacy of Politics in Building Effective States, Institutions and Governance for Economic Growth and Social Development'. Joint Leadership Programme, unpublished.

Lwanda, J. 2005. 'Changes in Malawi's Political Landscape between 1999 and 2004: Nkhope ya Agalatiya'. In B Immink, B Mhango, M Ott \& C Berries (eds). The Power of the Vote: Malawi's 2004 Parliamentary and Presidential Elections. Zomba: Kachere Series. Balaka: Montfort Media.

Magolowondo, A \& L Svasand. 2009. 'Political Parties in the 2009 General Elections'. Paper presented at the May 192009 Malawi Post Election Conference organised by GTZ Forum for Dialogue and Peace, Crossroads Hotel 23 to 26 June.

Malawi Electoral Support Network (MESN). 2009. A Report on May 192009 Presidential and Parliamentary Elections. Blantyre: MESN.

Malumelo, R \& V Njikho. 2009 'Participation of Women in Politics in Malawi: A Critical Analysis'. Paper presented at the May 192009 Malawi Post Election Conference organised by GTZ Forum for Dialogue and Peace, Crossroads Hotel 23 to 26 June.

March, J \& J Olsen. 2006. 'The Logic of Appropriateness'. M Rein, M Moran \& R Goodin (eds). The Handbook of Public Policy. Oxford: Oxford University Press.

Merkel, W \& A Croissant. 2004. 'Conclusion: Good Governance and Defective Democracies'. Democratization 15(5).

Murithi, T. 2007. 'Reflections on Leadership: From OAU to the AU'. Conflict Trends 2.

Olsen, J. 2008. 'Change and Continuity: An Institutional Approach to Institutions of Democratic Government'. ARENA Working Paper No 15. Available at: www.arena.uio.no.

Patel, N. 2010. 'Malawi's 2009 Elections: A Critical Evaluation'. Paper presented at a Conference on Elections, Processes, Liberation Movements and Democratic Change in Africa organised by IESE and CMI, Maputo, 8-11 April. \&A Mpesi. 2009. 'Malawi General Elections 2009: The Politics of Nominations'. Paper presented at the May 192009 Malawi Post Election Conference organised by GTZ Forum for Dialogue and Peace, Crossroads Hotel, 23 to 26 June.

Phiri, F. 2008. 'Social Capital and the Fight against Corruption in Malawi'. Towards the Consolidation of Malawi's Democracy: Occasional Paper Series, East and 
Central Africa No 11. Malawi: Konrad-Adenauer-Stiftung.

Rakner, L. 2009 'The Management of the 2009 Electoral Process: The Role of the Malawi Electoral Commission'. Paper presented at the May 192009 Malawi Post Election Conference organised by GTZ Forum for Dialogue and Peace, Crossroads Hotel, 23 to 26 June.

_ \& LSvasand. 2005. 'May be Free but not Fair: Electoral Administration 19942004'.CMI working Paper 2005. Bergen: CMI.

Tsoka, M \& B Chinsinga. 2009. Afrobarometer Survey Malawi Round 4 Summary Results. Zomba: Centre for Social Research: Chancellor College.

Zeleza, P. 2009. Malawi's Watershed Elections of May 2009. Available at: www.zelez/ blogging/u-s-affairs/malawi's -watershed-elections-may-2009

\section{News Reports}

Daily Times, The. 2001. 'Third Term not for Donors but for UDF', 27 August 2001.

—. 2007. 'EC in a Mess ... One Commissioner Left: No By-Elections', 19

December.

—. 2008. 'Hopefuls to Pay MK 100,000', 4 December.

—. 2009. 'Polls: Muluzi to Pull Out, 24 January.

—. 2009. 'Government to Respect Opposition Veep', 25 June.

— 2009. 'Parties Endorse Presidential Election Results', 29 June.

—. 2009. 'Chitipa DPP Fans Stage Protests', 29 May.

- 2009. 'DC Rebuffs Chiefs on Chafukira', 28 May.

- 2009. 'Kayembe Beats JZU', 25 November.

—. 2010. 'Muluzi Meets UDF MPs', 6 January.

- 2010. 'Minister to Hire, Fire DCs', 10 February.

Malawi News. 2009. 'Tembo Wins', 8-14 May.

Nation, The. 2001. 'Makhumula Speaks Out - May be UDF is Full of Dead Wood', 1 August.

—. 2001. 'Makhumula Out of UDF Executive', 18 September.

- 2002. 'PAC Speaks on Third Term', 19 October.

- 2002.'Churches Hit Back at Government, Politicians', 24 October.

- 2002. 'Sonke Axed from Cabinet', 8 October.

- 2006. 'Bingu Wants S65 Out', 26 March.

- 2008. 'S65 First-Opposition', 17 April

—. 2008. No S65 No Parliament', 22 June

- 2008. 'No Budget No S65 - Bingu', 17 April.

- 2008. 'Budget and S65 - Government Rebuffs Clergy's Package', 30 June.

_. 2008. 'Speaker Still Tied on S 65', 24 April.

- 2008. 'UDF, MCP Want 2 Seats Each in EC', 16 January. 
___. 2008. 'Electoral Commissioners Case: Muluzi, Tembo to Appeal', 18 January.

- 2009. 'S65 Saga', 9 April.

—. 2009. 'DPP Conduct in Parliament Unhealthy', 23 November.

- 2010. 'MPs to Vote in Assemblies', 3 February.

- 2010. 'Councillors to be Reduced by Half', 3 February.

- 2010. 'MHRC Backs Police Act', 10 February.

- 2010. 'MCP Blasts Local Government Bill as Parliament Passes the Bill', 10 February.

Nation on Sunday, The. 2009. 'UDF Gives Up on Muluzi's Candidature', 26 April.

Weekend Nation. 2009. 'Police Bill Proposes Suspension of Officers with STIs', 21 November.

_ 2010. I Never Said Govt Would Vet NGO Statements', 27 March.

—. 2010. 'Tembo Wins', 8 May. 